\title{
Immunoglobulin Light Chain, Kappa
}

National Cancer Institute

\section{Source}

National Cancer Institute. Immunoglobulin Light Chain, Kappa. NCI Thesaurus. Code C16718.

Immunoglobulin Light Chain Kappa is one of two Ig light chain types. Each Ig molecule is typically composed of two heavy chains and two light chains. Ig kappa light chains contain a variable and a constant region. Kappa light chains are encoded by multiple $\mathrm{V}, \mathrm{J}$, and C gene segments, which are separated in the genomes of cells undifferentiated with regard to antibody gene expression. Diversity in the kappa light chain $\mathrm{V}$ region arises during differentiation of an activated (kappa-type) antibody-producing B-cell from variable recombination of kappa $\vee$ genes with kappa J genes and somatic point mutation, which plays a major role in antibody diversity. (from OMIM and $\mathrm{NCl}$ ) 